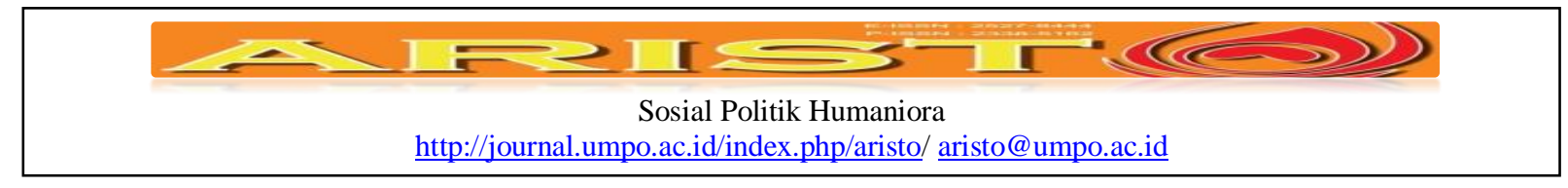

\title{
Peningkatan Kapasitas Manusia Sebagai Fokus dari People Centered
} Development

\author{
Purwowibowo, Kris Hendrijanto $^{2}$, Pra Adi Soelistijono ${ }^{3}$ \\ ${ }^{12}$ Program Studi Ilmu Kesejahteraan Sosial, Fakultas Ilmu Sosial dan Ilmu Politik \\ 3Program Studi Ilmu Hubungan Internasional, Fakultas Ilmu Sosial dan Ilmu Politik \\ Universitas Muhammadiyah Jember \\ poerwowibowo@yahoo.co.id, kris.hendrijanto@gmail.com, praadisoelistijono@ymail.com
}

\begin{abstract}
This article discusses the development paradigm that focuses on human or people centered development. Many development paradigms have been applied in many developing countries, but the results have not been satisfactory. During this time the various paradigms emphasize economic growth, equity of development, and others, but the distortion of development appears everywhere. For example, development by emphasizes economic-growth was followed by massive environmental damage. In addition, poverty is still a portrait of people in developing countries, although the country is experiencing high economic growth. In realizing a prosperous society free of poverty, a new strategy or development paradigm that emphasizes its human factors are needed. In this case, this paradigm discusses the importance of the human element as the 'core' of development itself. If human beings are capable, have sufficient knowledge, adequate skills by themselves poverty will be reduced. Therefore, this paradigm more implies that is a 'capacity building ' of human beings so that it can become the subject of development and not just as an object of development themselves. Capacity building can be achieved through social development that emphasizes elements of education, knowledge, and skills so that they can try or do entrepreneurship and open their own job opportunities. Many cases, various development paradigms that emphasize economic growth are not able to absorb the available labor so that many are unemployed. With the ability of human or people, they have will be able to open their own business and do not depend on the provision of employment from the government. In the end they are able to alleviate self-poverty.
\end{abstract}

\section{Keyword: Economic Growth, Capacity Building, Entrepreneurship}

\begin{abstract}
Abstrak
Artikel ini membahas tentang paradigma pembangunan yang menitik beratkan pada manusia (people centered development). Banyak paradigma pembangunan yang telah diterapkan di banyak negara berkembang, tetapi hasilnya belum memuaskan. Selama ini berbagai paradigma menekankan pertumbuhan ekonomi, pemerataan pembangunan, dan lainnya, namun distorsi pembangunan muncul di mana-mana. Sebagai contoh, pembangunan yang menekankan pertumbuhan ternyata diikuti oleh kerusakan lingkungan yang sangat masif. Selain itu, kemiskinan masih menjadi potret masyarakat di negara berkembang, walaupun negara tersebut mengalami pertumbuhan ekonomi yang cukup tinggi. Dalam mewujudkan masyarakat yang sejahtera dan terbebas dari derita kemiskinan, diperlukan strategi baru atau paradigma pembangunan yang menekankan faktor kualitas manusianya. Dalam hal ini, paradigma ini membahas pentingnya unsur manusia sebagai 'inti' dari pembangunan itu sendiri. Jika manusianya mampu, mempunyai pengetahuan cukup, ketrampilan yang memadai dengan sendirinya kemiskinan akan dapat dikurangi. Oleh karena itu, paradigma ini lebih mengisyaratkan 'capacity building' dari manusia sehingga mampu menjadi subyek pembangunan dan bukan hanya sebagai obyek pembangunan semata. Akhirnya, peningkatan kapasitas manusia dapat dicapai melalui pembangunan sosial yang menekankan unsur
\end{abstract}




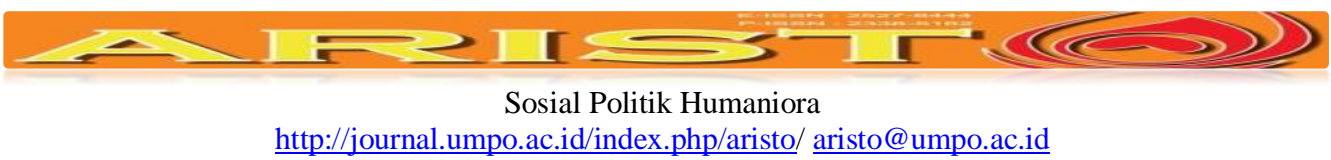

pendidikan, pengetahuan, dan ketrampilan sehingga mereka bisa berusaha atau melakukan wirausaha dan membuka peluang kerja sendiri. Banyak kasus, berbagai paradigma pembangunan yang menekankan pertumbuhan ekonomi tidak mampu menyerap tenaga kerja yang tersedia sehingga banyak sekali yang menganggur. Dengan kemampuan yang dimiliki mereka akan mampu membuka usaha sendiri dan tidak menggantungkan dari penyediaan lapangan kerja dari pemerintah. Pada akhirnya mereka mampu mengentaskan kemiskinan diri sendiri.

\section{Kata Kunci : Pertumbuhan Ekonomi, Kualitas Manusia, Wirausaha}

\begin{tabular}{|ll|}
\hline Submite & $:$ 30 Oktober 2017 \\
Review & $:$ 20 Januari 2018 \\
Accepted & $:$ 30 Juni 2018 \\
Surel Corespondensi & $:$ hayat.150318@gmail.com \\
\hline
\end{tabular}

\section{Pendahuluan}

Di era industrialisasi merupakan suatu masa yang tidak sejalan atau searah antara pencapaian pembangunan bidang teknologi dan juga bidang ekonomi bagi kehidupan masyarakat secara keseluruhan. Secara substansial keduanya mencapai keberhasilan dalam membawa pengaruh luar biasa dan sangat luas bagi penduduk di Negara Industri Barat pada umumnya, yang telah memberikan inspirasi mengenai visi global tentang pembangunan satu dunia dan memimpikan suatu kondisi tanpa ada kemiskinan pada masyarakatnya. Industrialisasi itu sendiri merupakan kesuksesan dari suatu model perencanaan pembangunan yang digagas dalam bentuk 'Marshall Plan' dan mampu mempercepat rekonstruksi kembali Eropa dari kehancuran setelah Perang Dunia Kedua dan mendorong suatu pencapaian tujuan satu dunia yang sejahtera. Visi global tersebut menyebar dengan cepat dan sangat luas sehingga mempengaruhi jutaan orang di berbagai belahan dunia dan bangsa dengan beberapa tahapan pembangunan ekonomi. Rahasia keberhasilan itu, diperkiraan sebagai artikulasi dari penerapan teori pembangunan saat itu dan disertai dengan tingkat pertumbuhan ekonomi tinggi melalui investasi besar-besaran dalam bidang industrialisasi. (Magid, 2012)

Teori Marshall tersebut memperkirakan bahwa negara yang selalu setia mengejar pertumbuhan ekonomi dengan suatu resep kebijakan ekonomi, secara perlahan dapat mengembangkan sektor ekonomi mikro yang mandiri sehingga dapat mengurangi kemiskinan di negara berkembang (Green, 2006). Dengan model ini pada akhirnya semua warga negara dapat mengakses keuntungan dari berkembangnya kehidupan masyarakat modern yang didukung sektor ekonomi mikro. Strategi pembangunan demikian berasal dari teori yang disebut 'konsentrasi produksi' dengan menekankan perhatian pada semua sumber daya dalam mencapai 


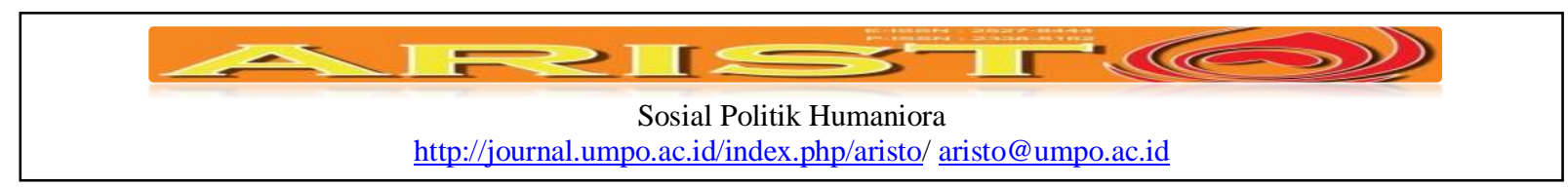

kemungkinan pertumbuhan ekonomi secara maksimun. Berbagai sarana dan prasarana managemen dikembangkan dan diperluas untuk membantu menentukan keputusan yang tepat agar pengalokasian sumber daya secara konsisten dapat dilakukan dengan tepat sebagai prioritasnya.

Semua kegiatan didasarkan atas maksud untuk mendapatkan keuntungan bagi semua manusia sehingga strategi dan metodologi tersebut pada awalnya disebut dengan pembangunan berpusat pada produksi (Wong and Fung, 2017). Para penganutnya memperkirakan bahwa penekanan satu pemikiran dalam produksi akan secara otomatis dapat mengubah peningkatan keuntungan bagi semua orang dalam suatu negara. Sedangkan indikator dan kebijakan yang menjadi kriterianya adalah dalam periode tertentu biasanya dapat diukur dengan produksi yang dihasilkan baik secara individu maupun masyarakat.

Selanjutnya, kedua pakar di atas menjelaskan bahwa dalam model ini, dapat disebut dengan investasi untuk pembangunan dan pengembangan sumber daya manusia. Secara rutin bisa dibenarkan pada tataran dasar - yakni para pekerja mendapatkan hasil yang lebih tinggi dalam bentuk pembayaran gajinya dalam proses produksi yang merupakan alternatif investasi tidak hanya karena mereka mendapatkan keuntungan secara langsung dari pertumbuhan ekonomi tetapi juga mendapatkan keuntungan lain secara tidak langsung.

Sesungguhnya, pertumbuhan ekonomi yang berbasis pusat produksi bukan hanya sekedar teori, tetapi merupakan hal yang sangat rumit dalam merealisasikannya. Suatu definisi yang jelas dari tujuan pembangunan dan merupakan suatu resep kebijakan untuk dapat diterapkan. Namun, visi demikian, merupakan suatu keyakinan yang sangat kuat bahwa berdasarkan suatu sistem produksi masal pertumbuhan ekonomi dapat dicapai melalui pembentukan pusat produksi sebagai suatu paradigma pembangunan yang diterapkan. Di beberapa negara Eropa, penerapan teori tersebut dengan membentuk pusat produksi mengalami keberhasilan, namun setelah diterapkan di negara berkembang dan berada di luar Eropa banyak mengalami kegagalan. Pertumbuhan ekonomi tidak diikuti dengan tingkat kesejahteraan masyarakatnya. Bahkan, penerapan paradigma pertumbuhan tidak menghasilkan keuntungan, namun hasilnya adalah 'tumpukan' hutang dan kerusakan lingkungan. Atas dasar tersebut kemudian muncul perkembangan paradigma yang disebut dengan 'teori dependensi' (Cardoso, F.H. and Falleto, E., 1979). 


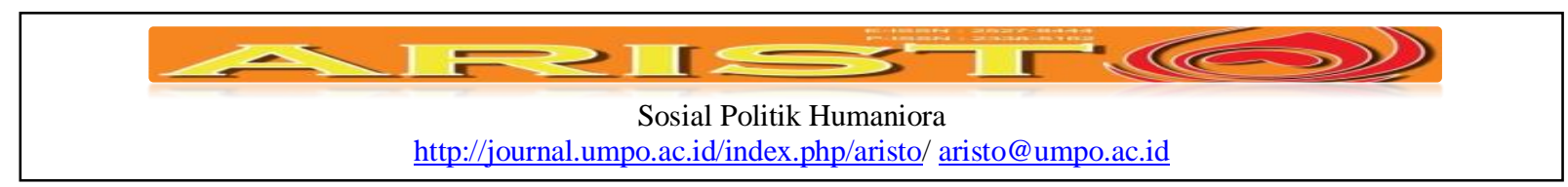

Teori dependensi atau paradigma ini berkembang di akhir tahun 1960-an, yang melakukan kritik terhadap keterbatasan mengenai teori pertumbuhan neo-klasik. Kritiknya secara substansial muncul dari kalangan ilmuwan atau pakar terutama barisan ekonom juga. Para pakar menyadari bahwa teori merembes ke bawah (trickle-down effects) seperti dikemukakan oleh Ambrose et al. (2013), baik secara ekonomi maupun keadilan sosial diperkirakan secara teoritis dan praktis mengalami kegagalan.

Sebaliknya, justru kebalikannya yakni pengaruh merembes ke atas (trickle-up) yang tidak pernah dipahami secara tuntas sehingga diperlukan bakat berwirausaha, tersedianya lapangan kerja, dan suatu kebijakan dari bawah ke-atas (Ghatak, 2007). Dengan menguji dan memahami kembali yang terjadi dan dimulai akhir tahun 1960-an sampai awal tahun 1970-an, maka diperlukan suatu keberanian untuk berkomitmen di seluruh dunia bahwa perlu menempatkan secara langsung tiga tantangan pusat pembangunan untuk mewujudkan kesejahteraan masyarakat. Pertama. adalah pengurangan kemiskinan bagi masyarakat di negara berkembang, kedua perlindungan kapasitas produksi berdasarkan sumber daya lingkungan dan tidak menimbulkan kerusakan, dan ketiga adalah pemberdayaan manusia melalui peningkatan partisipasi di dalam proses pembangunan dengan model bottom-up. Komitmen demikian disertai dengan menguji kembali teori dan resep yang digunakan terkait dengan teori pusat produksi. Ketiga tantangan tersebut dirujuk dalam pembangunan yang diprakarsai PBB yakni MDGs (UNO, 2000) dan SDGs (UNO, 2015).

Model pertumbuhan dengan mendatangkan teknologi baru yang efisien diyakini dapat menghasilkan pertumbuhan ekonomi secara substansial terkait dengan penyerapan dan produktivitas tenaga kerja industri perkotaan (Gomulka, 2006). Namun, dalam kenyataannya menurut paradigma dependensi kebijakan tersebut tidak dapat menciptakan lapangan kerja baru pada tingkat bawah sehingga tidak sepadan antara investasi dengan penciptaan lapangan kerja. Dengan memberikan tekanan pada strategi pertumbuhan ekonomi 'murni', sesungguhnya strategi tersebut justru sebaliknya dan menjadi bukti yang didasarkan atas asumsi yang keliru yakni bahwa negara berkembang dan miskin menjadi lebih miskin karena mereka tidak mempunyai tenaga kerja potensial produktif untuk mendukung penerapan paradigma pertumbuhan.

Dalam hal ini, keyataannya pada masyarakat luas di negara berkembang bahwa secara sosial budaya masalahnya adalah sikap malas sehingga tidak mampu bekerja secara produktif 


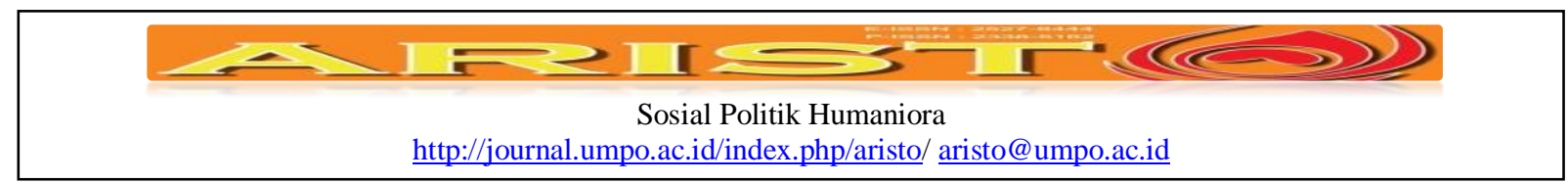

secara ekonomi. Sikap demikian berkaitan dengan dorongan yang rendah untuk berprestasi (McClelland, 1961) dari masyarakat di negara berkembang memang rendah. Hal tersebut terkait dengan kebiasaan masyarakat yang melakukan kegiatan secara komunal dan tidak produktif dalam pencapaian pekerjaan masyarakat. Kebiasaan mereka dengan kegiatan yang bersifat subsisten dan terjadinya 'involusi pertanian' (Geertz, 2016) sehingga tidak banyak menghasilkan suata karya tertentu secara individual maupu masyarakat.

Dipihak lain, masyarakat kecil di negara berkembang secara subsisten mampu dan mahir membuka lapangan kerja secara sendiri sebagai pedagang kecil. Berbagai pekerjaan informal, seperti tukang rongsokan besi, pengumpul barang bekas, pengangkut air, dan pedagang kecil yan mampu menyediakan kesempatan untuk hidup (Sangeeta and Erwan, 2006). Dengan realitas yang demikian, banyak pakar yang menganalis dan mencurahkan perhatiannya guna mengatasi masalah sosial yang muncul di negara berkembang adalah dengan menambah jumlah pekerjaan yang bisa disediakan untuk mengatasi tambahan dan pertumbuhan tenaga kerja dengan kualitas yang lebih baik. Selain itu, perlu juga mendorong dan memberikan pelatihan sehingga kapasitas masyarakat dapat meningkat

\section{Hasil dan Pembahasan}

\section{Perspektif Pembangunan Berpusat Pada Manusia}

Perspektif pembangunan yang menekankan kapasitas pada manusia, terus mendapatkan kritikan tetapi juga banyak yang mengakui sebagai paradigma pembangunan yang menjanjikan. Hal ini terkait dengan beberapa hasil penelitian yang telah dipublikasikan mulai tahun 1974 sampai 2003 oleh Bank Dunia dan Studi Pembangunan Institute Sussex yang mengisyaratkan paradigma baru terkait pertumbuhan ekonomi yakni pertumbuhan dan pemerataan (Sumawinta, 2004)

Model ini strateginya adalah memperluas penggunaan produktivitas sumber daya dalam skala kecil di bidang pertanian dan sektor informal perkotaan sehingga dapat membuka lapangan kerja bagi sebagian besar rumah tangga orang miskin. Model itu direkomendasikan juga dalam strategi pembangunan perdesaan yang tekanannya adalah peningkatan akses bagi petani kecil dan buruh tani yang bekerja di sawahnya sendiri. Mereka diberikan air bersih, kredit usaha, dan berbagai fasilitas lainnya untuk mendukung dan dapat memberikan mereka kesempatan untuk meningkatkan produktivitasnya. Selain itu, di negara-negara Asia telah dikembangkan program 


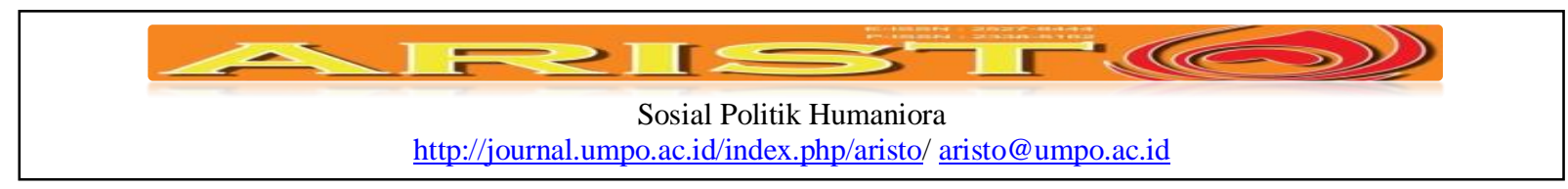

satu desa satu produk sehingga bisa mendorong dan mewadahi pertumbuhan ekonomi perdesaan (Natsuda, et al., 2012).

Sedangkan strategi di wilayah perkotaan ditekankan pada pembukaan kesempatan untuk meningkatkan produktivitas para pekerja subsisten sebagai produsen kecil melalui pemberian seluas-luasnya akses terhadap perubahan kebijakan. Selama ini, kebijakan bersifat diskriminatif kepada orang miskin di perkotaan sehingga mereka tidak mampu bertahan hidup - karena termarjinalkan oleh berbagai kebijakan yang diambil oleh pemerintah setempat. (Mulyadi, 2017)

Tema lain yang menujang munculnya perspektif pembangunan manusia juga diperkenalkan melalui kebijakan mengenai kebutuhan dasar manusia. Seperti kebutuhan sekolah, kesehatan dengan menganjurkan dan memperluas kesempatan untuk mendapatkan pendidikan yang murah dan layanan kesehatan yang mudah bagi sebanyak mungkin masyarakat bawah. Salah satu untuk dapat mengukur hal tersebut adalah Indeks Kualitas Hidup Fisik atau The Physical of Life Index yang dikembangkan sebagai alternatif dari Produk Nasional Brutto untuk mencapai tujuan pembangunan yang berbasis pada kapasitas manusia dan kesejahteraan sosial. (Larson and Wilford, 1979)

Dalam hal ini, pengembangan pemikiran sangat penting dengan disertai memperkenalkan reformasi kebutuhan manusia dalam prioritas pembangunan. Dengan berbagai kegiatan yang diprogramkan untuk mendukung pertumbuhan dengan pemerataan, maka prioritas menyediakan kebutuhan dasar berupa pendidikan dan kesehatan sangat penting. Dua hal ini bukan hanya sebagai alternatif melainkan prioritas yang harus ditekankan sebagai realisasi dari strategi pembanguman yang diterapkan. Dengan adanya penyesuaian di dalam kedua prioritas tersebut maka akan dpat diwujudkan perspektif dari paradigma 'people-centered development atau PCD (Corten, 1987).

Selain itu, dengan mengembangkan tiga pusat tantangan pembangunan seperti dijelaskan di atas maka pengentasan kemiskinan dapat segera terwujud. Pada era dekade lalu, sesungguhya merupakan waktu yang membawa ketenangan dan keharmonisan karena adanya keberhasilan dalam pengembangan pembangunan yang dilaksanakan. Hal tersebut terkait dengan adanya perkembangan tekonologi yang dapat dimanfaatkan untuk membantu kehidupan manusia. Manusia sudah merasa memerlukan bantuan teknologi dalam kehidupannya sehingga memuculkan kesadaranya tentang keterbatasan manusia dengan segala potensi yang ada. 


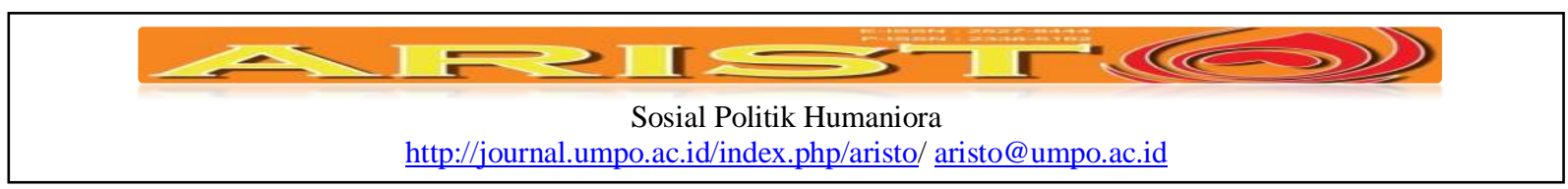

Meskipun tampak harmonis antara kehidupan manusia dan lingkugannya, tetapi masih ada hal perlu dikembangkan lagi. Oleh karena itu, hal tersebut mendorong para pakar mengembangkan pemikirannya tentang perspektif dari PCD dalam kerangka menyempurnakan paradigma pembangunan berpusat pada produksi dan membuka seluas-luasnya kemungkinan baru untuk menciptakan suatu masyarakat global yang sungguh-sungguh harmonis dalam kehidupan yang sejahtera dengan dukungan kelestarian lingkungan (Giddings, 2002).

Para pakar yang menganut paradigma pembangunan yang berfokus pada manusia, mengemukakan bahwa situasi kemanusiaan pada saat ini dalam perspektif perubahan sosial jangka panjang dan terus berlangsung. Argumen dasarnya adalah mereka mengembangkan suatu masyarakat industri yang didukung oleh masyarakat pertanianKeduanya adalah suatu masa transisi penting termasuk perubahan besar mengenai keberadaan nilai sosial masyarakat, struktur sosial, dan teknik produksi yang terus berkembang. (Mardzuki, 2014).

Suatu tranformasi sosial menuju suatu model masyarakat post-industri yang lebih pantas bagi negara dan bangsa yang lebih ramah di seluruh dunia yang berdasarkan pertanian (agricultural based) guna lebih maju, dengan melakukan langkah cepat menuju masyarakat industri. Di dalam era industrialisasi demikian seharusnya lebih banyak menciptakan suatu kondisi yang dapat mendorong dan mendukung terjadinya suatu tranformasi (perubahan). Suatu perubahan sosial yang dapat menciptakan kemungkinan pencapaian suatu masyarakat global bagi semua orang yang bisa memberikan kesempatan untuk merealisasikan atau mewujudkan potensi yang dimilikinya.

Salah satu hal yang sangat penting saat ini peran teknologi informasi, sudah menjadi pemain utama dalam kehidupan manusia terutama dalam proses pembelajaran masyarakat, maka yang perlu disadari adalah bahwa masyarakat manusia berada dalam suatu terminologi yang kenyataan hidup di dalam suatu planet bumi yang kecil. Hal ini karena jarak tidak menjadi penghalang manusia berinteraksi dengan orang lain di seluruh muka bumi ini. (Kwatolo, 2010)

Akibat dari realitas ini, dapat digambarkan bahwa suatu dasar alternatif ekonomi, yakni dengan mengeksplorasi reorientasi mengenai nilai-nilai dasar kemanusiaan yang diperlukan untuk hidup harmoni melalui proses alamiah dan membahas alternatif yang bisa dibuat terkait dengan bentuk organisasi (lembaga) yang tepat di dalam mengelola sumber daya yang ada. Persaingan memperebutkan sumber daya alam khususnya semakin meningkat sehingga menimbulkan banyak dinamika kemiskinan (BPS, 2016). Meskipun secara absolut kemiskinan 


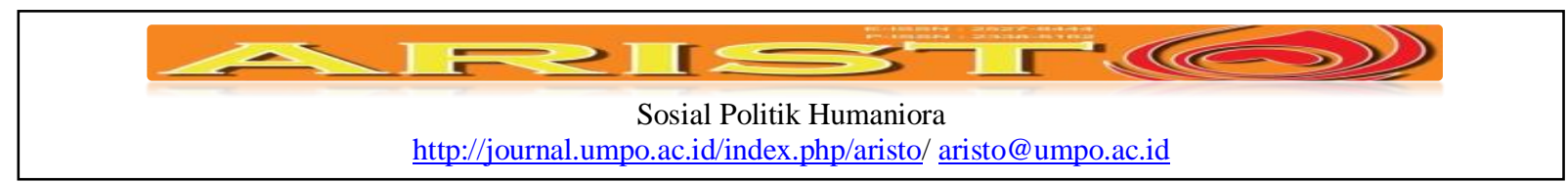

akan berkurang secara berangsur-angsur melalui proses perubahan sosial yang dilakukan tetapi masih banyak tantangan yang harus dicarikan jalan keluarnya melalui transformasi sosial yang dilakukan. Dalam hal ini, dinamika kemiskinan menjadi penting dan terus diperdebatkan melalui perbaikan sistematik yang terus-menerus dilakukan.

Pendukung perspektif dari munculnya paradigma PCD adalah membahas dan mengkritisi masalah definisi dengan mengedepankan isu-isu berdasarkan pada pilihan rekayasa sosial yang tepat bagi tujuan yang ingin diwujudkan. Dalam hal ini, fokusnya adalah pada teori pembelajaran sosial / social learning dan aplikasinya di dalam membuat pembelajaran lebih cepat dan efektif bagi individu dan lembaga sosial. (Maisto, 1999).

Selain hal itu, para pakar juga memperdebatkan pula fungsinya paradigma tersebut dalam perubahan sosial sebagai metodologinya. Sedangkan fokusnya pada perhatiannya terhadap sistem produksi, sistem pendidikan, dan sistem layanan kesehatan. Selain itu, paradigma ini juga harus menitikberatkan pada manusia sebagai subyek pembangunan dan kesejahteraan mereka, dengan penekanan pada pentingnya wilayah dan kepercayaan diri masyarakat.

Hal ini sebagai petunjuk dasar implementasinya, sehingga dapat memberikan pilihan terbaik dalam menggunakan sumber daya lokal di bawah kendali masyarakat lokal untuk memenuhi kebutuhan mereka sendiri sehingga terjadi 'self help to them selves' (Oliver, 1996), dari masalah kemiskinan yang dialami.

\section{Kerangka People Centered Development}

PCD sesungguhnya lebih menekankan pada pemberdayaan manusia melalui peningkatan kapasitasnya, sehingga mampu mengendalikan kehidupan mereka sendiri dengan melakukan pengelolaan terhadap sumber dayanya. Dalam hal ini, mereka mampu menciptakan sumber kehidupan rumah tangganya dan secara langsung dapat mengejar pembangunan nasional yang diprogramkan sebagai suatu upaya mencapai kesejahteraan sebagai wujud dan realisasi dari tujuan akhir PCD. Meskipun suatu langkah baru dalam mewujudkan kesejahteraan masyarakat yang dilakukan pemerintah, namun PCD terkadang mendapatkan kritik dari berbagai kalangan dan banyak pakar. (McGinty, 2002).

Kompleksitas isu terkait dengan PCD seringkali dikaitkan dengan lembaga sosial modern saat ini yakni suatu lembaga yang demokratis sampai kepada terwujudnya birokrasi di bidang bisnis, dan lembaga perburuhan yang condong melakukan pembelaan terhadap ketidakberdayaan 


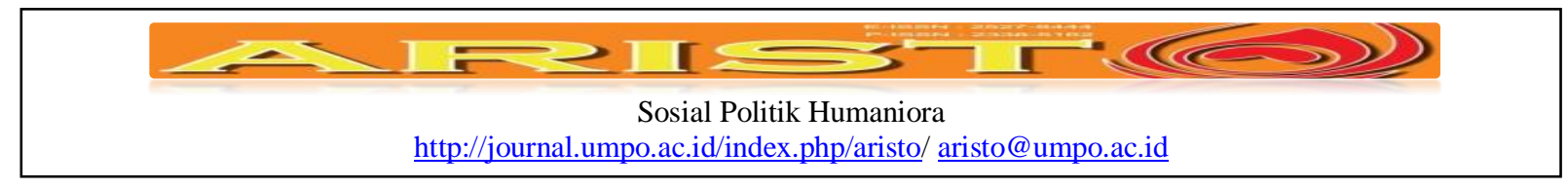

masyarakat. Selain itu, ketidakberdayaan manusia seringkali menjadi sasaran kebijakan yang memarjinalkan mereka. Satu hal penting dalam PCD adalah tanggung jawab penuh terhadap keberadaan dan pembelaan orang miskin baik di perkotaan maupun di perdesaan. Oleh karena itu, masyarakat miskin menjadi persoal penting dalam PCD karena mereka merupakan bagian besar masyarakat. Dengan membahas secara holistik sebagai strategi penting dalam pembanguan suatu negara dan bangsa, maka argumen logis perlu dijabarkan untuk mendukung kerangka PCD.

Konsep sentral dari PCD sangatlah sederhana. Konsep tersebut sebagai suatu pendekatan pembangunan yang memperhatikan proses yakni berasal dari inisiatif yang kreatif dari masyarakat atau orang-orang yang menjadi sumber daya utama pembangunan dan materinya. Selain itu, sangatlah penting memperhatikan konsep dari sisi kesejahteraan spiritual sebagai akhir dari proses dan implementasi pembangunan yang diprogramkan. Kalau menengok kegagalan terbesar dari model pembangunan konvensional (Majid, 2012), sebelumnya yang bersifat sosialis dan kapitalis, pada dasarnya keduanya mengandalkan pusat produksi dengan sistem produksi masal. Dalam hal ini, asumsi yang dibangun adalah pemenuhan kebutuhan manusia harus didahulukan karena pertambahan atau pertumbuhan penduduk terkait dengan kebutuhan dasar yang diperlukan sebagai sarana terpenuhi kehidupan. Dalam pembangunan konvensional, bagi yang beruntung dan dapat berpartisipasi dalam keseluruhan pembangunan maka akan mendapatkan kehidupan dengan mudah, terutama bagi masyarakat yang terlibat di dalam birokrasi, baik swasta maupun publik. Mereka dapat memenuhi kebutuhan hidupnya dengan mudah karena mendapatkan akses terhadap sumberdaya dalam rumah tangganya dan tidak terbatas dalam memperoleh kesempatan berbagai bidang untuk menciptakan kreativitas dirinya. Bagi masyarakat yang kurang beruntung dan tidak bisa berpartisipasi secara penuh di dalam proses pembangunan, maka mereka terjerumus dengan kehidupan yang marginal sebagai makhluk manusia dan harkat serta martabatnya bisa turun di tengah kehidupan masyarakat.

Dengan sistem sosialis dan kapitalis dengan mengandalkan pusat produksi dan sistem produksi masal, maka dalam waktu yang sama permintaan akan kebutuhan barang meningkat tajam. Guna mensuplai hal tersebut dapat dilihat bahwa kedua sistem dengan menggunakan berbagai perusahaan-perusahaan yang mendorong banyak pihak dalam masyarakat untuk melakukan pengrusakan (eksploitasi) terhadap sumber daya alam sehingga membahayakan ekosistem secara keseluruhan bagi kehidupan di bumi, baik manusia maupun binatang dalam menjaga kelangsungan atau kelestarian hidupnya. 


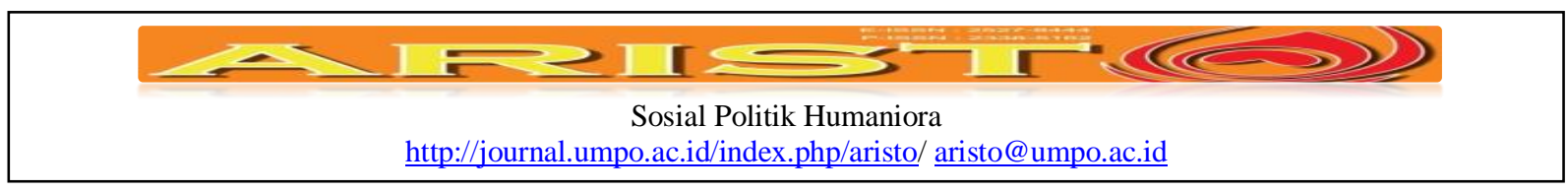

Dengan bayangan demikian kemudian muncul kesadaran tentang dehumanisasi (ketidakmanusiawian), ketidak-adilan, dan lingkungan yang tidak lestari yang mengakibatkan model pembangunan konvensional mulai ditinggalkan dan kemudian memunculkan langkah alternatif. Banyak alternatif dan pilihan program sangat meyakinkan sehingga dapat digunakan secara substansial dan dapat meningkatkan produktivitas hasil untuk memenuhi kebutuhan dan perkembangan jumlah penduduk dunia. Namun, langkah yang diambil harus merupakan langkah yang beriringan dan harmonis dengan kebutuhan dasar yakni, partisipasi masyarakat yang seluasluasnya, pemerataan dan kelestarian lingkungan hidup (UNO 2015).

Dari pengalaman yang telah lalu disarankan terhadap semua negara dan bangsa yang peduli terhadap kesejahteraan penduduknya untuk segera mencari suatu langkah yang tepat dengan menggunakan eksperimen atau percobaan. Hal ini dapat dijadikan suatu alat perencanaan baru yang mendukung definisi baru dari masalah pembangunan. Dengan usaha demikian diharapkan tercapai reorientasi kelembagaan melalui pengelolaan sumber daya masyarakat secara produktif - khususnya sumber daya tanah dan air - mengembalikan pengendaliannya pada masyarakat lokal yang menggantungkan kehidupan pada lingkungannya. Namun, para pembela terhadap praktik pembangunan konvensional tidak akan ragu menjaga dan mempertahankan model pembangunan tersebut dengan asumsi bahwa semua pembangunan yang dilaksanakan bermaksud untuk menguntungkan dan mensejahterakan semua masyarakatnya.

Dalam kenyataannya, banyak kejadian bahwa secara substansial bahwa pembangunan konvensional yang berfokus pada sistem produksi terkadang mengalami kendala atau distorsi (Midgley, 1995), sehingga pendekatan tersebut banyak mendapatkan kritikan. Alasan lain dari pembela paradigma konvensional adalah bahwa program pembangunan demikian merupakan suatu pendekatan yang efektif pada masanya dan mampu merealisasikan potensi produksi yang ada guna mewujudkan produksi masal bagi umat manusia. Selain itu, pembangunan konvensional dengan basis menciptakan sistem produksi masal terkadang tidak mampu memenuhi kebutuhan masyarakat yang terus berkembang. Dengan berbagai kendala tersebut kemudian pembangunan yang menekankan kapasitas manusia menjadi sangat penting dan secara singkat dapat dikemukakan ciri dari pembangunan konvensional dan pentingnya PCD sebagai berikut: 


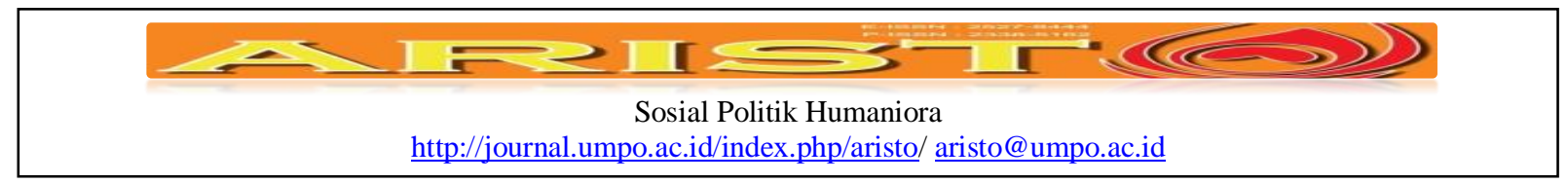

1. Industrialisasi seringkali mengalahkan bidang pertanian, padahal bidang tersebut merupakan bidang sangat penting karena sebagaian besar masyarakat di dunia ini menggantungkan kehidupannya.

2. Wilayah perkotaan memang merupakan komunitas yang lebih kompleks daripada perdesaan, namun jangan dikesampingkan bahwa wilayah perdesaan merupakan tempat sebagaian besar penduduk hidup dan mensuplai kebutuhan masyarakat kota.

3. Sistem sosialis dan kapitalis dalam pembangunan konvensional seringkali melewati batas kepemilikan mengenai aset produktif dan komunal, sehingga hasil produksi atau produktivitasnya hanya menguntungkan sedikit orang kota daripada kepentingan banyak orang.

4. Penggunaan modal melebihi batas optimal sumber daya manusia yang digunakan, akibatnya modal mendominasi dan sangat kuat sehingga pada akhirnya memperdaya orang miskin yang tidak memiliki modal.

5. Eksploitasi terhadap sumber daya alam dan lingkungan terjadi sangat masif padahal kegiatan demikian hanya untuk mencapai kekayaan material yang berjangka pendek. Sedangkan untuk memulihkan kembali sumber daya yang ada dan rusak dibutuhkan waktu dan biaya yang sangat banyak. Memulihkan kembali lebih berat daripada melakukan konservasi awal.

6. Model pembangunan konvensional berbagai program saling ketergantungan dalam skala produksi sangat besar dan didasarkan pada kemajuan kebutuhan internasional yang berbeda. Oleh karena itu, diperlukan produksi dalam skala kecil dan lokal dengan melakukan adaptasi serta mengorganisir kepercayaan lokal yang kuat sehingga menghasilkan kondisi ekonomi yang tangguh. Selama ini, pembangunan di banyak negera berkembang menhasilkan kondisi ekonomi yang rapuh dan mudah terpengaruh kekuatan ekonomi kapitalis dunia.

7. Banyak ditemui di dalam produksi masal ternyata menggunakan teknologi yang tidak efisien sehingga memerlukan biaya operasional tinggi, mengotori lingkugan dan tidak adaptif. Namun anggapan demikian dapat pula dimanipulasi secara praktik politik di berbagai sistem sosial.

Dengan berbagai asumsi dan alternatif seperti dijelaskan di atas, kini tiba saatnya melihat dan memahami pemikiran Korten tentang pencetus paradigma PCD. Menurutnya, dominasi dari era industrialisasi yang berpusat pada produksi masal adalah logika yang dibangun bahwa produksi dan tujuan akhirnya merupakan hal yang penting dan pokok, yakni untuk mewujudkan 


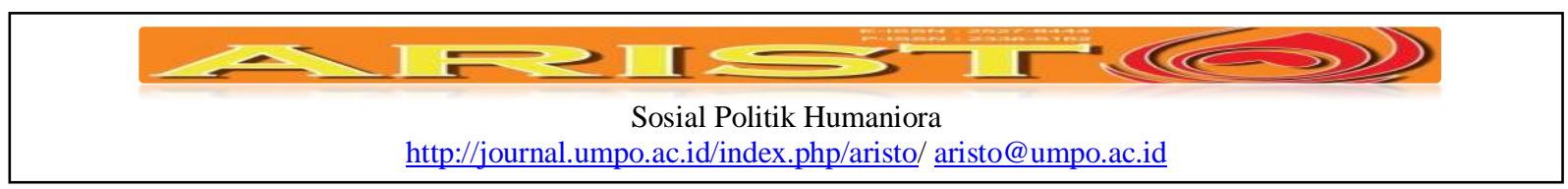

kesejahteraan masyarakat. Pusat-pusat produksi ada nilai-nilainya tertentu, sistem, dan metode praktis yang digunakan untuk mengeksploitasi dan memanipulasi sumberdaya alam untuk kepentingan produksi. Hal tersebut dimaksudkan agar apa yang dilakukan dapat meningkatkan arus barang yang lebih cepat, standar, dan selalu tersedia dalam jumlah besar sehingga layanan kepada masyarakat dapat diberikan dengan leluasa. Dengan kondisi demikian, maka seluruh konsumen yang memerlukan kebutuhan akan barang tertentu tersedia cukup banyak dan dapat menjamin kepastian terpenuhinya kebutuhan konsumen, meskipun mereka dalam jumlah yang sangat banyak. (Korten, 1987)

Pusat-produksi sebagai basis industrialisasi dapat menciptakan sejumlah besar birokrasi yang mengorganisir masyarakat ke dalam sistem produksi yang efisien - pengendalian terpusat dan fungsional. Selain itu, suatu pasar dan sistem keuangan dapat dikendalikan secara efisien guna kepentingan semua bangsa di seluruh dunia. Pengelolaanya dirancang dengan suatu system terkendali terpusat untuk memaksimalkan tingkat pertumbuhan yang diinginkan. Jika semua yang dirancang dapat berjalan dengan baik dan lancar, maka dapat menghasilkan dan mendorong perekonomian masyarakat secara keseluruhan. Hal tersebut akan mengindikasikan bahwa pertumbuhan perekonomian dapat diwujudkan dan suatu perubahan sosial yang secara otomatis terkait dengan peningkatan kesejahteraan seluruh masyarakat.

Selanjutnya keberadaan paradigma PCD juga sering menghadapi sejumlah kejadian yang membatasi dalam merealisasikannya. Hal ini sebagai suatu wujud dari suatu program pembangunan semata dan tidak hanya kepada sistem nilai individu dan struktur kelembagaan, melainkan juga keberadaan kerangka pemikiran teoritis dan metodologinya yang dapat mengidentifikasi masalah yang muncul dan mencari solusi yang diberikan, baik terkait dengan masalah individu maupun masalah kelembagaanya. Diterimanya model managemen krisis menurut Pearson and Judith (1998), adalah suatu upaya untuk mencari solusi model pembangunan ekonomi ortodoks dan klasik yang ditengarai kurang berhasil dalam menjembatani praktik politik-ekonomi dunia yang menguntungkan negara maju. Oleh karena itu, para pakar dan pemimpin di seluruh dunia berusaha mencari formulasi berupa instrumen-instrumen kebijakan yang dapat digunakan, namun, kadangkala beberapa pemikiran yang dikemukakan atau disampaikan digunakan dalam waktu terbatas karena dalam era berikutnya pemikiran tersebut tidak digunakan sama sekali. Padahal upaya yang berkelanjutan tersebut sesungguhnya dapat digunakan sebagai acuan untuk memperbaiki program berikutnya. 


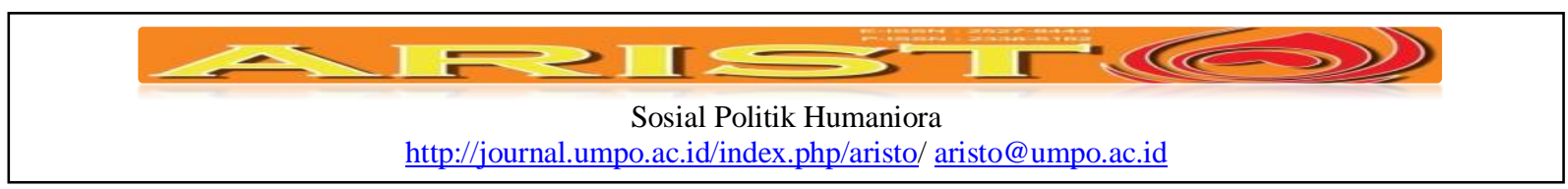

Suatu alternatif paradigma pembangunan sangat dibutuhkan untuk memperbaharui model sebelumnya. Di masa sebelum post-industrialiasasi, (Featherstone, 1990). program dan strategi pembangunan menghadapi kondisi dan situasi yang sangat berbeda dari era industrialisasi sesudahnya. Sekarang waktunya menggunakan potensi baru sangat penting dalam rangka mewujudkan pembangunan untuk memperkuat kemampuan manusia atau kapasitas manusia dan kesejahteraannya. Hal tersebut terkait langsung dengan pemerataan, dan keberlanjutan yang menurut para pakar dan ahli kebijakan disebut dengan PCD. Namun, untuk dapat mewujudkan kerangka teotis dan praktis dari konsep ini masih menemui hambatan, tidak hanya terkait dengan konsep utama dari PCD tetapi juga metode penerapannya. Sekali lagi di dalam era postmodernisasi dan industrialisasi, semua elemen dan unsur pembangunan harus diarahkan pada suatu paradigma baru yang dilandasi suatu alternatif penting tentang PCD, khususnya berkaitan dengan suatu alternatif pemikiran, nilai, dan rekayasa sosial serta penggunaan teknologi yang dapat digunakan untuk mendukung PCD tersebut.

Ada banyak alasan dan pemikiran untuk menyakini bahwa paradigma PCD yang berkembang saat ini munculnya terkait dengan perubahan sosial yang terjadi secara global. Perubahan sosial tersebut secara integral dan berlangsung bersama-sama di seluruh masyarakat dunia. Tentu saja, dominasi logis dari paradigma PCD adalah pembangunan sosial (Midley,1995), yakni suatu pembangunan yang menyeimbangkan ekologi manusia dengan terwujudnya kreativitas seluruh masyarakat. Sedangkan inti atau fokusnya adalah pertumbuhan manusia tentang kapasitasnya atau potensi diri yang dimilikinya. Hal ini dapat ditandai dengan berkembangnya peran individu yang selama ini menjadi obyek pembangunan dan kemudian individu sebagai subyek pembangunan. Dengan kata lain, manusia dan masyarakat menjadi aktor dari program pembangunan yang dilaksanakan sendiri, mengikuti proses perencanaan, mengelola sumber daya alam yang lestari. PCD berarti menempatkan substansi nilai masyarakat lokal sangat penting dan berusaha menyandarkan sifat harmonis atas berbagai perbedaan. Berkembangnya model pembangunan PCD harus didukung oleh suatu sistem organisasi yang kuat dan efisien sehingga mengutungkan masyarakat dan organisasi sosial dan pada akhirnya memunculkan kepercayaan masyarakat.

Barang produksi yang diproduksi secara masal oleh pusat-pusat industri memang merupakan hal yang sangat penting terkait dengan upaya mencapai kesejahteraan manusia dan kepercayaan masyarakat itu sendiri. Hal ini sesugguhnya merupakan inti dari PCD yang 


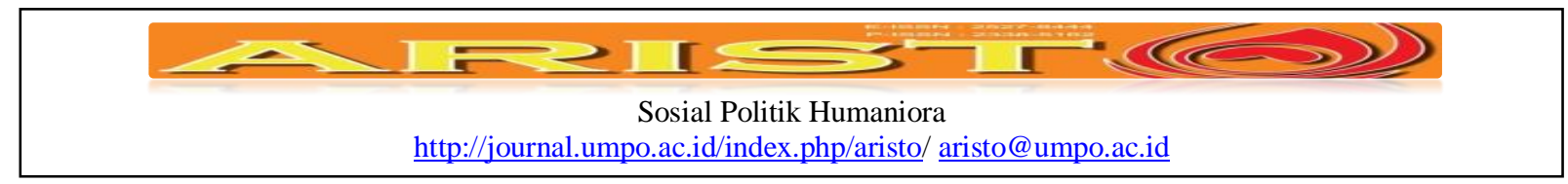

mendasarkan suatu pemikiran bahwa kekayaan sendiri yang dimiliki berasal dari partisipasinya dan bukan dari pemberian atas dasar belas kasihan dan amal tertentu. Di dalam kegiatan produksi yang dilakukan masyarakat akan menentukan kualitas diri mereka sendiri yang dilandasi dengan kerja yang telah dilakukan. Oleh karena itu, pemikiran penting yang membedakan antara pusat produksi dengan PCD adalah pada mulanya manusia dan masyarakat hanya sebagai penyumbang dalam proses sistem produksi dan pada akhirnya justru sekarang sistem produksi tidak bisa berjalan manakala tidak ada partisipasi dari masyarakat sebagai penyokong utama sebagai tenaga kerjanya (Hendry, 2011).

Suatu pemahaman penting dari perbedaan antara pusat manusia (people centered) dan pembangunan pada pusat produksi adalah pada esensinya tentang pilihan mengenai rekayasa sosial (Peltier, 2006). Dalam hal ini pilihan dari rekayasa sosial haruslah tepat dan sesuai dengan tujuan program pembangunan yang dicanangkan sebelumnya. Oleh karena itu, sejak dari awal metode perencanaan, bentuk organisasi yang netral, dan lainnya harus mendukug dan condong terhadap maksud dari nilai yang dituju. Rekayasa sosial dari PCD pada produksi, misalnya suatu bentuk sistem komando dalam organisasi, bebas nilai, metode analisis kebijakan yang tepat, metodologi penelitian sosial yang dilandasi atas prinsip ilmu pengetahuan ilmiah. Dengan demikian fungsi dalam sistem produksi dan alat, maka faktor manusia sebagai bagian inherent yang sangat penting dan tidak bisa dipisahkan, baik secara eksternal dan internal dari lingkungan dari penerapan PCD.

Perencanaan dan rekayasa sosial terkait dengan PCD terkadang berlawanan arus dengan paradigma sebelumnya. Hal ini ditunjukkan bahwa PCD ciri umumnya adalah berbentuk organisasi yang peran utamanya adalah individu dalam proses pengambilan keputusan. Model ini sering disebut sebagai aplikasi dari nilai humanisme atau kemanusiaan dalam mempertimbangkan semua kebijakan yang diambil dan ditentukan. Selain itu, model demikian merupakan proses pengembangan pengetahuan yang dilandasi oleh konsep dan metode pembelajaran sosial (social learning). Secara khusus sesungguhnya bermula dari perspektif fungsional, yakni didominasi oleh perencanaan dan pengelolaan sumber daya yang efisien dengan menggunakan model sistem pusat produksi

Suatu tantangan yang terus berkembang dan penting dalam PCD adalah reorientasi dan revitalisasi dari pengembangan birokrasi total pemerintahan untuk menjadi suatu organisasi efisien dan dapat memperkuat program pembangunan yang didalamnya didukung oleh anggota 


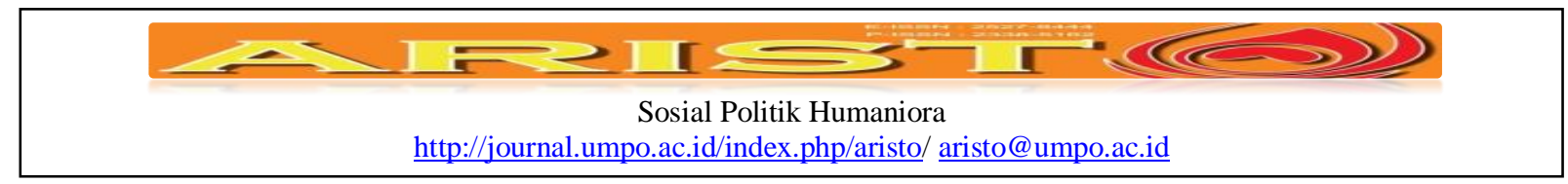

organisasi dan warga masyarakat. Dengan demikian maka layanan yang diberikan akan lebih maksimal dan memenuhi kebutuhan masyarakat. Melalui organisasi yang dapat menjadi wadah PCD maka dapat berfungsi sebagai sarana dan media di dalam mewujudkan peningkatan kapasitas masyarakat, baik secara individual maupun kelompok masyarakat. Menurut Battilana (2006), dengan organisasi sosial lokal dapat pula terbentuk suatu team work yang memadai di dalam masyarakat sehingga semua program dalam pembangunan yang fokusnya kapasitas manusia atau masyarakat menjadi sangat kuat. Karena individu dan masyarakat merupakan unsur utama dalam PCD, maka keberhasilan dari pembangunan yang menggunakan paradigma ini akan ditentukan pula oleh keberadaan sumber daya manusia baik secara individual maupun masyarakat tersebut. Dengan kata lain, komunitas masyarakat mempunyai peran penting di dalam kerangka jangka panjang untuk merealisasikan PCD karena individu dan masyarakat tidak dapat dipisahkan dalam kerangka komunitas di dalam memberikan kontribusi keberhasilan pembangunan yang telah direncanakan atau diprogramkan. Sekali lagi, dalam komunitas perlu terus dikembangkan proses pembelajaran sosial, karena hal ini akan dapat mewujudkan kapasitas masyarakat baik tentang pengetahuan dan ketrampilannya yang sangat dibutuhkan dalam PCD.

Dengan demikian dapatlah dikatakan bahwa tujuan dari membangun kekuatan berbasis pembelajaran sosial dalam paradigma PCD adalah memberikan layanan terbaik kepada seluruh individu dan masyarakat dengan melakukan program dan tindakan guna mempercepat munculnya kreativitas baru, daripada hanya berwujud konflik politik yang sulit dihilangkan. Proses persiapannya berlangsung lama melalui kegiatan kolektif dari kreasi manusia dan belajar sosial yang dimulai dari tidak mempunyai visi organisatoris, tidak ada pemimpin, tidak anggaran, tidak mengenal batas negara, melampaui ideologi tradisional dan kepentingan politik tertentu.

\section{Kesimpulan}

Berdasarkan pembahasan di atas dapat dikemukakan di sini bahwa pembangunan ekonomi yang menekankan pertumbuhan ekonomi yang tinggi dengan menggunakan pusat-pusat produksi memang mampu meningkatkan pendapatan masyarakat. Namun, model pembangunan demikian masih menyisakan distorsi, yakni kerusakan lingkungan dan kemiskinan. Oleh karena itu, diperlukan suatu paradigma pembangunan yang berpusat pada manusia, yakni PCD. 


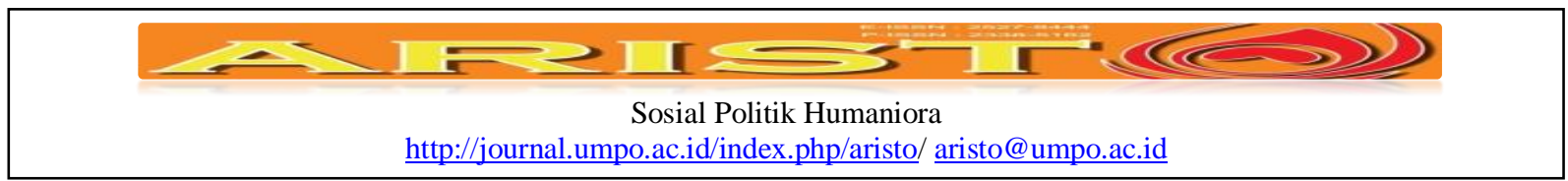

Paradigma ini diyakini bahwa untuk mengurangi kemiskinan dan membebaskan penduduk dunia dari kemiskinan dapat dilakukan dengan menekankan pembangunan pada manusianya, yakni suatu pembangunan yang titik beratnya atau fokusnya pada menusianya sendiri. Suatu pembangunan penekanannya pada kapasitas manusia yang terkait dengan pengetahuan dan ketrampilan sehingga individu dan masyarakat tidak hanya sebagai obyek pembangunan semata tetapi menjadi subyek dan perancang serta pelaku pembangunan itu sendiri. 


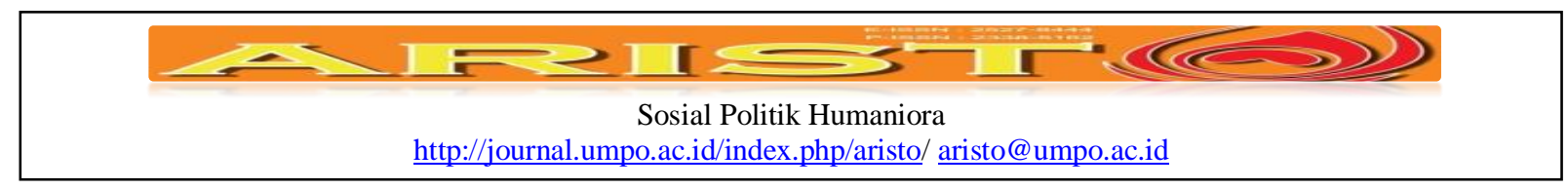

\section{Daftar Pustaka}

Aghion, P. and Patrick Bolton (1997). A Theory of Economic Studies. Vol. 64, Issue 2. April. Battilana, J. (2006). Agency and Institutions: The Eanbling Role of Individuals' Social Positions. $\begin{array}{lllll}\text { Sage } & \text { Journals. } & \text { Vol. } & 13 . & \text { Issue }\end{array}$ http://journals.sagepub.com/doi/abs/10.1177/1350508406067008

BPS (2016).Penghitungan dan Analisis Kemiskinan Makro Indonesia 2016.

Cardoso, F.H. and Falleto, E. (1979). Dependency and Development in Latin America. University of California Press. Los Angeles Magid, J. (2012). Marshall Plan. Advances in Historical Studies. Vol.1, No.1, 1-7 Published Online December 2012 in SciRes/http://www.SciRP.org/journal/ahs

Featherstone, M. (1990). Global Culture. Sage Journals. Vol. 7 No. 2 - 3. http://journals.sagepub.com/doi/abs/10.1177/026327690007002001?journalCode=tcsa

Geertz, C (2016) Involusi Pertanian - Proses Perubahan Ekologi di Indonesia. Penerbit: Komunitas Bambu. ISBN: 979-979-9542-38-3.

Giddings, B. et al. (2002).Environment, economy and society: fitting them together into sustainable development. View issue TOC. Volume 10, Issue 4.November 2002.Pages 187-196.

Hendry, C. (2011) Human Resources Management. A Analysis Approach to Employment. Routledge. Taylor and Francis Groups. London - New York.

Korten, D, C. (1987). "Third Generation NGO Strategies: A Key to People-Centered Development". World Development Pergamon Journals. Vol. 15 supplement. pp. 145 159.

Kwatolo, Y. (2010). Teknologi Informasi dan Komunikasi dalam Proses Pembelajaran.Jurnal Pendidikan Penabur. No.14/Tahun ke-9/Juni 2010.

Larson and Wilford (1979). The Physical of Life Index: A Usuful Social Indicator?. World $\begin{array}{lllll}\text { Development. } & \text { Vol. } & 9 ., & \text { Issue } & 6 .\end{array}$ http://www.sciencedirect.com/science/article/pii/0305750X79900949

Majid, M.S.A. (2012). Mengkritisi Teori Pembangunan Ekonomi Konvensional. Share: JurnalEkonomi dan Keuangan Islam. Vol. 1. No. 1.

Mardzuki, K. et al. (2014) Intersectoral Linkages in Malaysian Agricultural Industry: Identification of Key and Non Key Sector for Growth Promotion. Proceeding ITMAR. Vol. 1, 437-447 


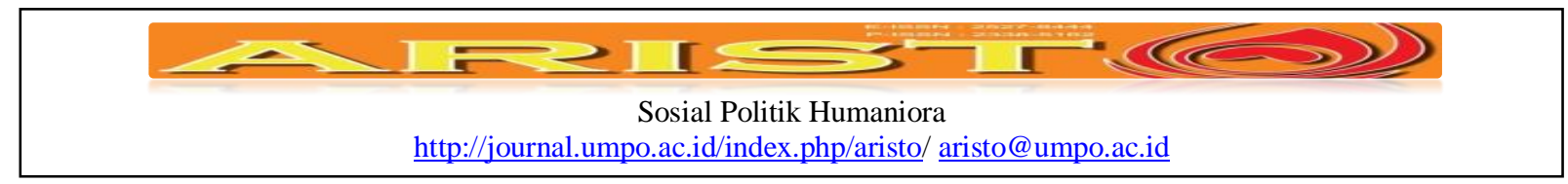

McGinty, S. (2002). Community Capacity Building. ERIC - Search Education Resources.https://eric.ed.gov/?id=ED473884

McClelland, D.C. (1961). The Achieving Society. Free Press, New York.

Midgley, J. (1995). Social Development : The Development Perspective in Social Welfare (pp. 1- 36) London: Sage Publication.

Mulyadi, M. (2017). Peran Pemerintah Dalam Mengatasi Pengangguran dan Kemiskinan Masyarakat. Kajian. Vol.21. No. 2 hal 221-236.

Oliver, M. (1996).Understanding disability: From theory to practice. American Psychological Association. 750 First Street NE, Washington, DC. http://dx.doi.org/10.1007/978-1-34924269-6

Pearce, D. W (1983). The Dictionary of Modern Economic. MacMillan Press. London.

Pearson, C. M. And Judith A. Clair (1998). Reframing Crisis Management. Academic Management Review. Vol. 23. No. 1.

Peltier, T. R. (2006). Social Engineering: Concept and Solution. Journal Information System $\begin{array}{llcl}\text { Security. } & \text { Vol } & 15 . & \text { Issue. }\end{array}$ 5.http://www.tandfonline.com/doi/abs/10.1201/1086.1065898X/46353.15.4.20060901/9542 7.3

Sumawinta, S. (2004). Politik Ekonomi Kerakyatan. Penerbit: PT Gramedia Utama Pustaka Utama Jakarta.

United Nation Organization. (2000). World Development Goals. United Nation Program. http://www.undp.org/content/undp/en/home/sdgoverview/mdg_goals.html

United Nation Organization. (2015). Sustainable Development Goals. United Nation Program. https://sustainabledevelopment.un.org/topics/sustainabledevelopmentgoals

Wong, C-Y and Fung, H-N (2017). 'Science-technology-industry correlative indicators for policy targeting on emerging technologies: exploring the core competencies and promising industries of aspirant economies'. Scientometrics. Vol. 111:841-867. 